\title{
THE EFFECTS OF INTERNATIONALIZATION OF PRODUCTION ON THE TURKISH MANUFACTURING INDUSTRY: AN APPLIED STUDY ON FOREIGN-INVESTED MANUFACTURER-EXPORTERS*
}

\author{
Emre ERGÜVEN 1
}

\begin{abstract}
This study investigates the effects of the transnational corporations' organization of the production all over the world on the Turkish manufacturing industry (MI) and determines how the Turkish MI is articulated to this global organization. To this aim, it analysed foreign-invested manufacturers in the top-1000 exporters list of the Turkish Exporters Assembly. Semi-structured interviews were conducted with the senior officials of the fifteen out of 101 firms who accepted their titles being revealed. Consequently, internationalization of production reinforced foreigndependent structure of the Turkish MI; and Turkey, an intermediate zone between advanced Western countries and cheap-labour Asian countries, seems as backyard of Europe: R\&D units are few, imported inputs are high, value-added is low, there is specialization in the particular stages of the medium-low and medium-high technology production, relatively qualified and cheap intermediate staff is abundant, the highest part of exports is made to Europe, the MI is part of the global production and supply networks. And more importantly, this study shows that it is no more possible for Turkish MI to compete on the basis of cheap labour; and the contradictory policies to overcome this situation are far from increasing the competitive power of the Turkish MI.
\end{abstract}

Keywords: Foreign direct investments, internationalization of production, Turkish manufacturing industry, transnational corporations

JEL Classification: F21, F23, F62

\section{ÜRETIMIN ULUSLARARASILAŞMASININ TÜRKIYYE IMALAT SANAYİSİ ÜZERINDEKİ ETKILERİ: YABANCI SERMAYELİ IMMALATÇI-IHHRACATÇILAR ÜZERINE BİR UYGULAMA}

\begin{abstract}
Özet
$\mathrm{Bu}$ makale, çokuluslu şirketlerin üretimi dünya çapında örgütlemesinin Türkiye imalat sanayisi üzerindeki etkilerini ele alıyor ve Türkiye imalat sanayisinin bu küresel örgütlenmeye nasıl eklemlendiğini ortaya koyuyor. Bu amaca yönelik olarak, Türkiye İhracatçılar Meclisi'nin ilk 1000 ihracatçı listesindeki yabancı sermayeli imalatçı-ihracatçılar ele alınmış, adının açıklanmasını kabul eden 101 firmadan 15'inin yetkilileriyle yarı yapılandırılmış mülakat yapılmıştır. Sonuç olarak üretimin uluslararasılaşması Türkiye imalat sanayisinin dışa bağımlı yapısını pekiştirmiştir; gelişmiş Batı ülkeleriyle ucuz işgücüne dayalı Asya ülkeleri arasında ara bir bölge olan Türkiye Avrupa'nın arka bahçesi olarak nitelendirilebilir: Ar-Ge birimlerinin kısıtlı düzeyde olduğu, yüksek ithal girdi kullanıp düşük katma değer yaratan, orta-düşük ve orta-yüksek teknolojili üretimin belli aşamalarında uzmanlaşmış, görece nitelikli ve ucuz ara elemanların ağırlıkta olduğu, ihracatının önemli bölümünü Avrupa'ya yapan, ana firmanın kurduğu küresel üretim ve tedarik ağlarının bir parçası olan bir çerçeve söz konusudur. Daha da önemlisi, bu çalışma Türkiye imalat sanayisinin artık ucuz işgücüne dayanarak rekabet edemeyeceğini göstermektedir; ayrıca bu durumu alt etmek için uygulanan çelişkili politikalar Türkiye imalat sanayisinin rekabet gücünü artırmaktan oldukça uzaktır.
\end{abstract}

Anahtar Kelimeler: Doğrudan yabancı yatırımlar, üretimin uluslararasılaşması, Türkiye imalat sanayisi, ulusötesi şirketler

JEL Kodları: F21, F23, F62

\footnotetext{
This paper is based on my PhD thesis and I would like to gratefully thank Prof. Okan Tuna, Aysu Göçer, Birol Keleş, Cihan Salim, Didem Köseoğlu, Esen Gündoğan, Esra Ergüven, Güzide Aslı Köylü, Hakan Durmaz, Mehmet Göçmen, Mustafa Çıkrıkçığlu, Mustafa Mente, Osman Kurt, Tayfun Batan, Umut Kalaycı, and Yasin Kara for their help in getting the appointments with senior officials of the firms in the sample.

${ }^{1}$ Dr. Öğr. Üyesi, Beykoz Üniversitesi, emreerguven@ beykoz.edu.tr
} 


\section{Introduction}

Internationalization of capital that has come to the fore again from the 1970s and 1980s onwards occurred in different forms: massive increase in world trade (internationalization of commodity capital), expansion of financial capital movements (internationalization of money capital), and organization of production by the transnational companies (TNCs) via foreign direct investments (FDIs) in all over the world (internationalization of productive capital). Though it is mostly difficult to make a separation between these three forms, this study will mainly focus on the third one, namely on the internationalization of production.

Internationalization of production can be traced with the following indicators: inward FDI flows and FDI stock, inward FDI flows as a percentage of gross fixed capital formation, inward FDI stock as a percentage of GDP, sales of foreign affiliates, value-added created by foreign affiliates, total assets of foreign affiliates, exports of foreign affiliates, employment by foreign affiliates. As will be seen below, all of these indicators provide enough evidence for the internationalized production in the world economy.

Falling rate of profits from the late 1960s onwards; liberalization of capital movements in most countries, eliminating the barriers to FDIs, and the waves of privatizations as a result of the collapse of import-substitution industrialisation and Keynesian policies; regional integration initiatives; decreasing operational costs abroad boosted FDI flows and stocks in the last 30-40 years. The rate of increase in the FDIs has been much higher than the ones in both GDP and international merchandise trade.

Manufacturing industry is a critical sphere to which these FDIs go. Although the share of manufacturing industry in the total output and employment lags behind by far the share of services, the effect of the manufacturing industry on the overall economy surpasses its share. As Nixson (2002: 68) puts it, rapid increase in the productivity level of manufacturing industry, increasing returns to scale, rapid technological change and various dynamic externalities make manufacturing industry engine of growth.

Many thinkers addressed the issue of internationalization of production. John A. Hobson (2005: 51, 54, 71-76, 80-83, 106), Rudolf Hilferding (2006: 111-114, 122-128, 225, 301, 313-315, 317, 325), and V. I. Lenin (1964: 196-210, 238-239, 241) placed internationalization of production within their theories of imperialism and capital export (with Lenin's words, surplus capital was exported to the backward countries in order to increase profits since profits are high in the backward countries 'for capital is scarce, the price of land is low, wages are low, raw materials are cheap'). Steven Hymer (1960: 23-24, 38) came up with the concept of 'market power'. After the end of the World War II, internalization approach (by Richard Caves, Raymond Vernon, Alan Rugman, Peter J. Buckley and Mark Casson) came to the fore (Forsgren, 2008: 48-49). It focused on what was going on inside the TNC and reduced the motives of the TNCs to the minimization of costs. Similarly, John H. Dunning's (2001: 173-

190) ownership-location-internalization paradigm, Raymond Vernon's (1966: 190-207; 1979: 255-258) product cycle theory, John Cantwell's technological accumulation approach (Davis, 2004: 136-137), or Uppsala model (Johanson and Wiedersheim-Paul, 1975: 305-07) are all 'business' oriented approaches and far from explaining interdisciplinary processes. 
On the other hand, 'New International Division of Labour' approach ('a new division between high-tech production and industrial production using standard technologies replaced the previous division between industrialized centres and non-industrialized peripheries') of Fröbel et al. (1977; 1978) and 'commodity chain' approach (referring to 'a network of labour and production processes whose end result is a finished commodity') of Hopkins and Wallerstein $(1977 ; 1986)$ suggested a different framework based on capitalist world economy. Inspired by Hopkins and Wallerstein, Gereffi (1994) developed his own 'global commodity chain' analysis and introduced buyer-driven and producer-driven commodity chains. These led the way to the 'global value chain' and 'global production network' analyses, which come closer to business literature. ${ }^{2}$

These approaches deserve criticism for several aspects ${ }^{3}$ but the aim of this study is neither to determine their deficiencies nor to develop a new theory about global production. After all, (whether one argues for imperialism theories, business-oriented theories or chain/network analyses) there is a mechanism and organisation about international production and this fact has affected not only economic structures, relations of production, sub-sectors of manufacturing industry but also social structures and classes, education systems, political relations and balances of power between countries. This has had inevitably several impacts on Turkish manufacturing industry. The aim of this study is to analyse the effects of the TNCs' organization of the production all over the world on the Turkish manufacturing industry, and to determine how Turkish manufacturing industry is integrated to this global organization and the role of Turkish manufacturing industry in the resulting international division of labour.

This paper tries to analyse various dimensions of this process by using a qualitative method which has not been common to examine the effects of the TNCs on the Turkish manufacturing industry. And it critically evaluates the answers given by the interviewees together with the socio-economic structure of Turkey, and the positions of the foreign-invested firms in the economy.

To this aim, this study analysed foreign-invested manufacturers listed in the Turkish Exporters Assembly's top 1000 exporters research. There are 121 foreign-invested manufacturer-exporters in the list, among which twenty firms rejected to be named. Fifteen firms out of the remaining 101 firms were drawn by using simple random sampling method and semi-structured interviews with senior officials of these firms were hold. The questions posed to the participants are classified into three groups: foreign investment process, export products and production technology, integration into the world economy.

\section{Literature on FDIs in Turkish Manufacturing Industry}

The literature on foreign investments in Turkish manufacturing industry is limited to either specific sectors or some aspects of FDI (such as the motives, spillovers etc.), and most of the studies used quantitative methods (only the ones about textile and apparel industries used qualitative methods). I contribute to this literature by revealing the overall status of the foreign-invested manufacturing firms in Turkey and their position in the world economy with the help of an in-depth investigation and analysis.

\footnotetext{
${ }^{2}$ For a compact resume of commodity and value chain analyses see Bair (2005); and for an account of global production network analysis and its comprasion to the chain consepts see Henderson et al. (2002) and Coe et al. (2008)

${ }^{3}$ For a criticism of chain and network analyses see Selwyn (2012) and Selwyn (2016).
} 
A couple of researchers studied the motives behind FDI inflows to Turkey. Polat and Payalığlu (2015), using panel data for the period 2007-2012, argued that foreign investors in manufacturing industry disregard the political, economic and financial risks of Turkey, while tax rates, energy prices, turnover indices, and incentives given after the 2008 crisis play important roles to attract FDIs. In an early study, Tatoğlu and Glaister (1998) analysed location specific factors attracting Western FDI to Turkey and found that most important factors are 'market size, transferability of profits, growth rate of the Turkish economy and government policy towards FDI'. Based on Dunning's theory, Tatoğlu et al. (2003) investigates the factors determining the level of foreign equity shareholding in the TNCs' manufacturing affiliates in Turkey. Accordingly, the level of foreign ownership increases as the cultural distance between home and host countries decreases, the age of the affiliate increases, the capital size of the affiliate decreases, if they invest in industrially developed regions, if the concentration ratio of the target industry is either very high or very low, and when they do not diversify into unrelated areas. Ok (2004) asserted that economic and political stability is the most important factor driving FDIs to Turkey. Deichmann et al. (2003) found that 'agglomeration, depth of local financial markets, human capital, and coastal access dominate location decisions of foreign investors in Turkey'.

Tokatli and Tokatli et al. scrutinised Turkish clothing industry and revealed the upgrading stories of some Turkish clothing firms (Sarar, Mavi Jeans and Boyner), which were formerly contractors of giant global players, within the global clothing industry. They stress that although these movements cannot be generalised to the whole clothing industry, one should not disregard the possibilities of acquiring some autonomy and skills (e.g. Turkish contractors begin to undertake design processes) within the global networks (Tokatli, 2003; Tokatli, 2007; Tokatli and Eldener, 2004; Tokatli and Kızlgün, 2004; Tokatli et al., 2007). Another paper about the upgrading challenge of Turkish textile and apparel industries was written by Neidik and Gereffi (2006) who discussed the changing competitive power and strategies of the Turkish firms. On the other hand, Dikmen (2007) emphasized the heavily dependent structure of the Turkish textile and apparel industries on the global production chains with the help of a case study in Denizli. Another case study about the textile industry in Denizli was conducted with an interdisciplinary approach by Özuğurlu (2008), who depicted the transformation of this industrial city in its process of integration to the global production system as an industrial site full of contractors of TNCs and emphasized class formations during this process.

Özatağan (2011) explored the upgrading possibilities of the automotive industry and revealed that Turkish component suppliers gained design and product-development competencies; however, she argued that this is not a success of Turkish suppliers but it stemmed from the decisions of the global lead firms. In addition, the critical activities such as marketing and branding remain in the domain of the parent firms.

Kanberoğlu and Kara (2014) argued that FDIs have no significant effect on the value-added of Turkish manufacturing. One of the main conclusions of Taymaz and Özler (2007) who analysed foreign ownership in the Turkish manufacturing industry for the period 1983-2001 was that foreign investments tend to reduce domestic plants' survival probability since they have notable advantages about 'size of the plant, capital intensity, growth rate, and quality of labour force'. Another study by Atıcı and Gürsoy (2012) for the period 1993-2009 concluded that the increase in the share of foreign investors has a positive effect on the export performance of the Turkish manufacturing firms. Ebghaei and Akkoyunlu-Wigley (2018) estimated value added and total factor productivity equations for Turkish manufacturing firms for the period 2003-2011 and showed that export-oriented firms benefit more from the positive spillovers of FDI. Lenger and Taymaz (2006) who examined spillover impacts of FDIs on the innovation and technology transfer activities of Turkish manufacturing firms revealed that horizontal spillovers from foreign firms are insignificant, vertical spillovers do not exist in low-tech industries and are limited in medium- and high-tech industries. Çatık and Karacuka (2012) reached similar results. 


\section{Indicators of the Internationalization of Production}

The simplest definition of internationalization of production is the organization of production (by a firm) in more than one country via FDIs. Two basic concepts about FDIs are FDI flows and FDI stocks, which offer us considerable tools to measure to what extent the production process has gone international. FDI flows give us more accurate information on short term changes whereas FDI stocks stand as more stable indicators and are more appropriate for long term changes.

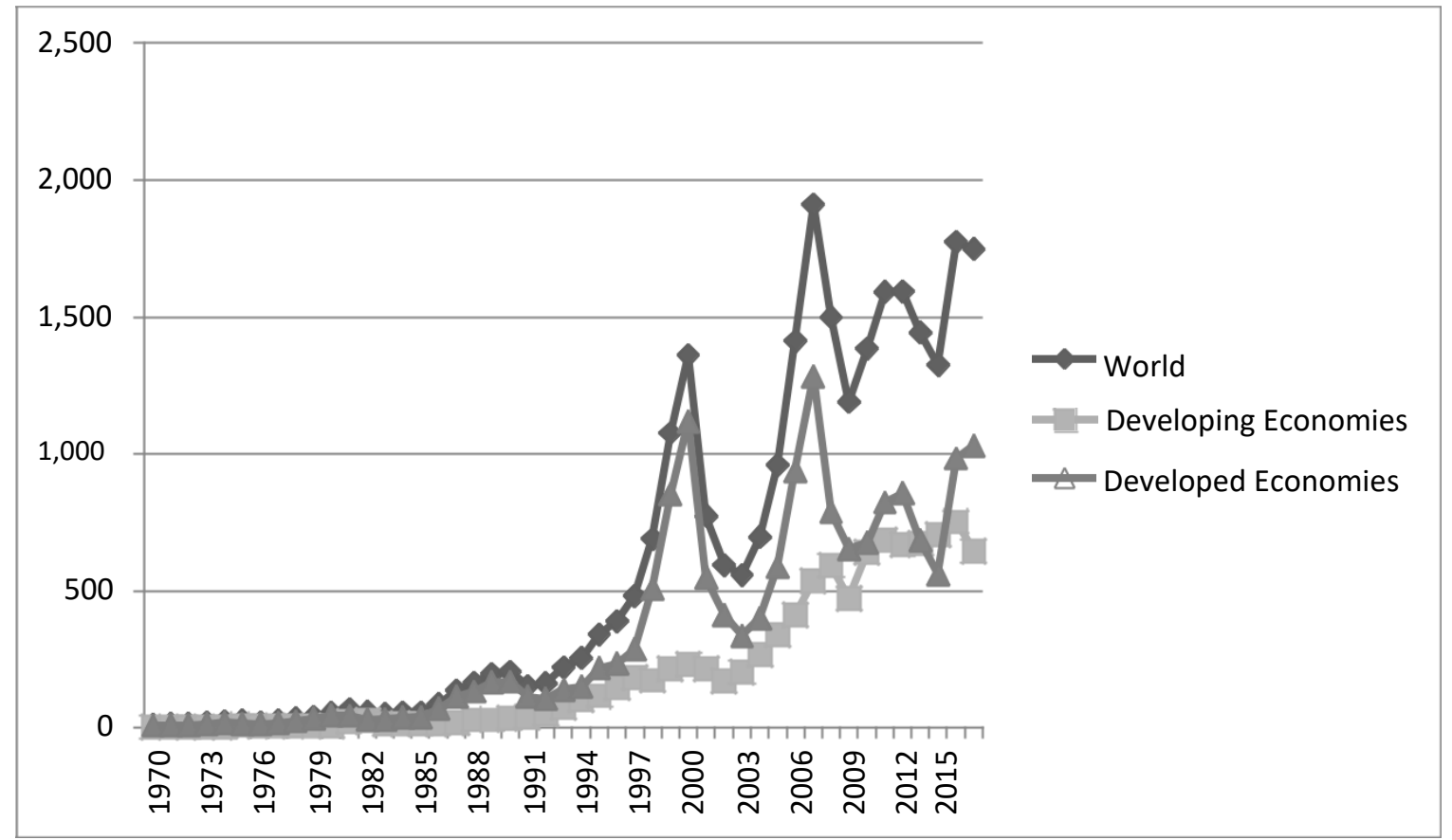

Figure 1. Inward FDI Flows to World, Developing and Developed Economies, 1970-2016 (billion USD at current prices)

\section{Source: UNCTAD Statistics}

Figure 1 and Figure 2 depict that FDI flows and stock in the world economy increased dramatically especially from 1980s on. Whereas FDI flows to developing economies surpassed FDI flows to developed economies recently (in 2014 for the first time according to UNCTAD statistics), inward FDI stock of developing economies is far from catching up with inward FDI stock of developed economies.

FDI inflows, after climbing up to 2 trillion USD just before the 2008 crisis, have oscillated around 1.5 trillion USD since then. As a corollary, FDI stock reached 25 trillion USD, amounting nearly one third of the world GDP, which shows the importance of foreign investments in generating world income. Similarly, inward FDI flows have made a considerable contribution to the making of gross fixed capital formation from the 1990s on: around 10-15 per cent (UNCTAD Statistics). 


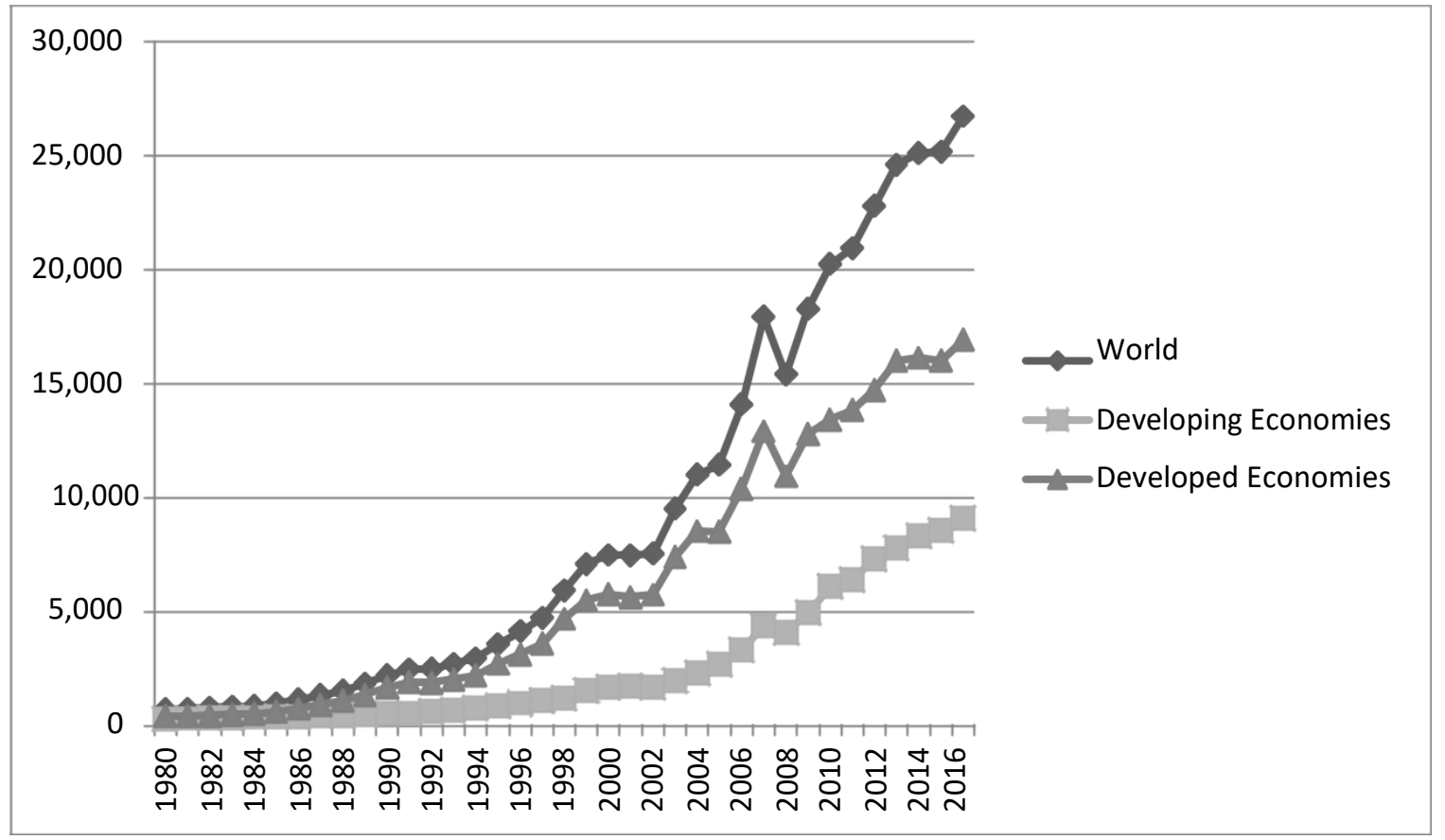

Figure 2. Inward FDI Stock of World, Developing and Developed Economies, 1980-2016 (billion USD at current prices)

\section{Source: UNCTAD Statistics}

Table 1 shows selected indicators about international production. Accordingly, sales, value added, total assets, exports and personnel of the foreign affiliates of the TNCs boomed in the last three decades: Between 1982 and 2016, sales of foreign affiliates increased by 15 times, total assets of foreign affiliates increased by 55 times, their exports increased by 11 times, and their employees increased by four times. As a result, their sales are now approximately half of the world GDP; their exports are about one third of the total exports of goods of services in the world. Total assets of foreign affiliates surpassed world GDP in 2006, and now are one and a half times larger than it. Although these figures represent both manufacturing and services, they give sufficient data about the dimensions of the internationalisation of production. 
Table 1. Selected Indicators of FDI and International Production, 1982-2016 (billion USD at current prices)

\begin{tabular}{|c|c|c|c|c|c|c|c|}
\hline Years & $\begin{array}{l}\text { Sales of } \\
\text { Foreign } \\
\text { Affiliates }\end{array}$ & $\begin{array}{l}\text { Value-Added } \\
\text { (Product) of } \\
\text { Foreign } \\
\text { Affiliates }\end{array}$ & $\begin{array}{l}\text { Total Assets } \\
\text { of Foreign } \\
\text { Affiliates }\end{array}$ & $\begin{array}{l}\text { Exports of } \\
\text { Foreign } \\
\text { Affiliates }\end{array}$ & $\begin{array}{l}\text { Employment } \\
\text { by Foreign } \\
\text { Affiliates } \\
\text { (millions) }\end{array}$ & $\begin{array}{l}\text { World } \\
\text { GDP }\end{array}$ & $\begin{array}{lr}\text { Exports } & \text { of } \\
\text { Goods } & \text { and } \\
\text { Services } & \end{array}$ \\
\hline 1982 & 2,530 & $623^{a}$ & 2,036 & 635 & 19.87 & 12,454 & 2,223 \\
\hline 1990 & 5,097 & 1,073 & 4,595 & 1,444 & 21.44 & 22,985 & 4,261 \\
\hline 1995 & 5,933 & $1,363^{\mathrm{a}}$ & 7,091 & $\ldots$ & $\ldots$ & 31,102 & 6,339 \\
\hline 1996 & 9,372 & $2,026^{\mathrm{a}}$ & 11,246 & 1,841 & 30.94 & 31,768 & 6,700 \\
\hline 1997 & 9,728 & $2,286^{\mathrm{a}}$ & 12,211 & 2,035 & 31.63 & 31,635 & 6,963 \\
\hline 1998 & 11,427 & $2,677^{\mathrm{a}}$ & 14,620 & 2,338 & 35.07 & 31,430 & 6,858 \\
\hline 1999 & 13,564 & $3,045^{\mathrm{a}}$ & 17,680 & 3,167 & 40.54 & 32,635 & 7,126 \\
\hline 2000 & 15,680 & $3,167^{\mathrm{a}}$ & 21,102 & 3,572 & 45.59 & 33,601 & 7,941 \\
\hline 2001 & 18,517 & $3,495^{\mathrm{a}}$ & 24,952 & 2,600 & 53.58 & 33,416 & 7,682 \\
\hline 2002 & 17,685 & $3,437^{\mathrm{a}}$ & 26,543 & 2,613 & 53.09 & 34,760 & 8,018 \\
\hline 2003 & 16,963 & $3,573^{\mathrm{a}}$ & 32,186 & 3,073 & 53.2 & 39,013 & 9,353 \\
\hline 2004 & 20,986 & $4,283^{\mathrm{a}}$ & 42,807 & 3,733 & 59.46 & 43,932 & 11,365 \\
\hline 2005 & 21,394 & $4,184^{\mathrm{a}}$ & 42,637 & 4,197 & 63.77 & 47,602 & 12,833 \\
\hline 2006 & 25,844 & $5,049^{\mathrm{a}}$ & 55,818 & 4,950 & 70 & 51,543 & 14,769 \\
\hline 2007 & 31,764 & $6,295^{\mathrm{a}}$ & 73,457 & 5,775 & 80.4 & 58,072 & 17,230 \\
\hline 2008 & 30,311 & $6,020^{\mathrm{a}}$ & 69,771 & 6,664 & 77.39 & 63,642 & 19,752 \\
\hline 2009 & 23,866 & 6,392 & 74,910 & 5,060 & 59.88 & 60,329 & 15,811 \\
\hline 2010 & 22,574 & 5,735 & \begin{tabular}{|l|}
78,631 \\
\end{tabular} & 6,320 & 63.04 & 66,010 & 18,836 \\
\hline 2011 & 24,198 & 6,260 & 83,043 & 7,436 & 67.85 & 73,380 & 22,367 \\
\hline 2012 & 25,980 & 6,607 & 86,574 & 7,479 & 71.7 & 74,958 & 22,735 \\
\hline 2013 & 33,775 & 7,562 & 95,230 & 7,688 & 71.3 & 77,040 & 23,419 \\
\hline 2014 & 33,476 & 7,355 & 104,931 & 7,854 & 75.57 & 78,914 & 23,799 \\
\hline 2015 & 36,069 & 8,068 & 108,621 & 6,974 & 79.82 & 74,696 & 21,073 \\
\hline 2016 & 37,570 & 8,355 & 112,833 & 6,812 & 82.14 & 75,649 & 20,580 \\
\hline
\end{tabular}

Source: UNCTAD Statistics for "World GDP" and "Exports of Goods and Services". UNCTAD, 1997: 4; UNCTAD, 1999:

9; UNCTAD, 2000: 4; UNCTAD, 2001: 10; UNCTAD, 2002: 4; UNCTAD, 2003: 3; UNCTAD, 2005: 14; UNCTAD, 2007:

9; UNCTAD, 2009: 18; UNCTAD, 2012: 24; UNCTAD, 2015: 18; UNCTAD, 2017: 26 for the remaining data.

${ }^{a}$ Data shows gross product rather than value added of foreign affiliates.

As for the sectoral breakdown of inward FDI stock, the share of manufacturing industry fell from 42.4 per cent in 1988 to 25.38 per cent in 2012. On the other hand, the share of services climbed to 64.17 per cent in 2012 from 43.9 per cent in 1988 (UNCTAD, 2014). This is not unusual but the importance of manufacturing industry lies in its ability to become the driving force of productivity growth, trade or innovation in an economy. So its importance should be evaluated by taking these aspects into consideration, and is indeed greater than it seems. 


\section{The Place of Turkish Manufacturing Industry in the World and Foreign Investments in Turkey}

Two developments in Turkish economy accompanied the aforementioned internationalisation of production and they closely interacted with each other: the transition to export-oriented strategy from import-substitution industrialisation and neoliberal market reforms (including privatisations, flexibilisation of the labour market, liberalisation of trade and investment regime etc.). Export-oriented strategy would let the sales of the final goods produced by the TNCs, while neoliberal reforms would attract more and more FDIs to Turkey.

As a result, the share of manufacturing industry in the exports of Turkey increased up to around 90 per cent after the 1980s; however, Turkish manufacturing industry is far from being competitive in terms of technology level.

Low technology manufacturing industry exports formed 30.4 per cent of the total exports in 2012 (33.3 per cent in 2017) while they formed 46.8 per cent in 2002. During the same period the share of high technology exports decreased from 6.2 per cent to 3.4 per cent (3.9 per cent in 2017) while medium-high technology exports range between 25-34 per cent. The decrease in low technology exports was replaced by the increase in medium-low technology exports: the share of medium-low technology exports climbed from 22.8 per cent to 37.8 per cent (28.3 per cent in 2017) (TÜiK, 2017; Sekmen, 2013: 11). Although there is a shift in Turkish manufacturing industry exports from low technology to medium-low technology, nearly two-third of the manufacturing industry exports contains low or medium-low technology. There is also an increase in the medium-high technology exports, which is directly related to the boost of automotive exports.

Turkish manufacturing industry, generating 0.9 per cent of world manufactures export, barely represents about two thousandths of the total high technology manufactures export (WTO; National Science Board, 2014: 66970; National Science Board, 2018: 1318-19). Furthermore, the share of value-added created by the Turkish manufacturing industry in the world manufacturing industry value-added decreased from 1.26 per cent in 1990 to 1.07 per cent in 2012 and 0.94 per cent in 2017 although the share of Turkey's GDP in the world GDP and the share of Turkish manufacturing exports and imports in the world manufactures trade increased in the meantime (National Science Board, 2012: 523-26; National Science Board, 2018: 1255, 1257; UNCTAD Statistics), which refers a considerable erosion in the capability of Turkish manufacturing industry to create value-added.

Last but not least, industry labour productivity growth of Turkey fell behind that of emerging economies in general. Although labour productivity growth in Turkey moved a little forward from 2000 to 2007, it turned to negative rates in the following five years and it is far from competing with the major industrial centres among the developing countries (see Table 2). Consequently, Turkish manufacturing industry is lagging behind in another sphere and it is foredoomed to low productivity. 
Table 2. Industry Labour Productivity Growth in Selected Countries, 1970-2014 (\%)

\begin{tabular}{|l|l|l|l|l|l|}
\hline Countries & $\mathbf{1 9 7 0 - 1 9 7 9}$ & $\mathbf{1 9 8 0 - 1 9 8 9}$ & $\mathbf{1 9 9 0 - 1 9 9 9}$ & $\mathbf{2 0 0 0 - 2 0 0 7}$ & $\mathbf{2 0 1 0 - 2 0 1 4}$ \\
\hline Developed Economies & 2.5 & 2.8 & 3.1 & 2.8 & 1.1 \\
\hline Argentina & 1.7 & -1.4 & 6.9 & -0.7 & -2.5 \\
\hline Brazil & 3.4 & -2.8 & 2.9 & 0.0 & -2.5 \\
\hline Chile & -0.3 & -0.5 & 6.2 & 0.1 & -1.8 \\
\hline Mexico & 0.6 & -1.7 & 0.4 & 0.6 & 3.7 \\
\hline China & -1.6 & 4.8 & 10.4 & 7.1 & 6.9 \\
\hline South Korea & 3.2 & 5.0 & 7.7 & 5.6 & 4.3 \\
\hline Indonesia & 3.2 & -0.4 & 2.3 & 2.4 & 0.8 \\
\hline Malaysia & 0.2 & 2.0 & 0.9 & 4.0 & 1.6 \\
\hline Philippines & 4.0 & -2.9 & -1.0 & 1.9 & 3.7 \\
\hline Thailand & 2.5 & 5.9 & 2.3 & 1.9 & 1.1 \\
\hline India & 2.3 & 1.3 & 0.7 & 3.3 & 0.5 \\
\hline Transition Economies & - & - & -5.8 & 4.6 & 3.0 \\
\hline Turkey & 5.0 & -0.4 & 0.6 & 2.6 & -0.3 \\
\hline
\end{tabular}

Source: UNCTAD, 2016: 69.

Turkey, consistently suffering a savings-investment gap, has been in need of foreign capital in various forms. Thus, always opened up to foreign capital, it further liberalized the legislation about foreign direct investments especially from 1947 onwards (most known arrangements were made in 1950, 1951, 1954, 1986, 1989 and 2003). But only in the 2000s did the FDIs begin to increase.

Both FDI inflows to and inward FDI stock of Turkey skyrocketed from $2001 \mathrm{on}$. Privatizations that could not be widely accomplished until these years have had a considerable effect on this boom. Similarly, the ratio of FDI inflows to gross fixed capital formation boomed after 2000: It climbed up to 16-17 per cent, and the average of the last ten years is nearly 10 per cent, which means that the potential contribution of FDIs to the gross fixed capital formation increased by ten times (UNCTAD Statistics).

Having revealed the dimensions of the FDIs all over the world and their importance in Turkish economy, this paper will now examine their effects on Turkish manufacturing industry with a special emphasis on how Turkish manufacturing industry has been integrated to the international production mechanisms.

\section{A Field Research on Foreign-Invested Manufacturer-Exporters in Turkey}

\subsection{Methodology}

In this study, which employed a semi-structured interview method, the universe is foreign-invested manufacturers listed in the Turkish Exporters Assembly's top 1000 exporters research conducted in 2012. By taking into consideration the universal definition of FDI, this research discarded the firms having less than 10 per cent foreign capital share. Accordingly, there are 121 foreign-invested manufacturer-exporters in the list, among which 20 firms rejected to be named. Fifteen firms out of the remaining 101 firms were drawn by using simple random sampling method (in case a firm declined to participate in the research, another random firm was drawn). 
I held semi-structured interviews with senior officials of these fifteen firms in 2013-2014. I used an interview form consisting of fifteen questions in three groups: foreign investment process, export products and production technology, integration into the world economy (see Appendix). I also addressed several probing questions in order to either clarify or to confirm some answers. I did not disclose the names of the firms and interviewees.

\subsection{General characteristics of the firms}

The sum of exports of the 101 firms in the universe was 18.2 billion USD in 2012 and it constituted 11.9 per cent of Turkey's export which was 152.46 billion USD that year. 100 firms (one firm did not declare the number of employees) employed 103,528 workers in 2012 whereas 4.42 million people are employed in the Turkish manufacturing industry. The employees of the firms in the universe formed 2.34 per cent of the total workforce in the Turkish manufacturing industry. Both ratios are considerable and show that the firms in the universe play an important role in the Turkish manufacturing industry.

The sum of exports of the 15 firms in the sample was 10.38 billion USD in 2012, which was 57 per cent of the exports of the firms in the universe. The firms in the sample employed 34,245 workers, which constituted 33.1 per cent of the employees of the firms in the universe. As a consequence, the firms in the sample largely represent the firms in the universe in regard to export and employment.

Nearly one fifth of the firms in the universe operate in the 'manufacture of motor vehicles, trailers and semitrailers,' and as a corollary five out of fifteen firms in the sample are from this sector. Then come 'manufacture of food products' and 'manufacture of chemicals and chemical products.' Although it was impossible to interview with firms from each sector, the firms in the sample are from nine different sectors out of 18 sectors in which the firms in the universe operate.

The number of firms with a foreign capital ratio of 100 per cent is more than the half of all firms both in the universe and the sample. Taking into consideration that a significant amount of the firms with a foreign capital ratio between $31-50$ per cent are joint ventures, there are only a few firms in which foreign investor's share is in the minority.

According to the number of firms, nearly half of the firms in the universe and the sample operate in medium-high technology industries. The firms operating in low technology industries follow them. According to their share in the total export, the largest part of the foreign investors operates in medium-high technology industries (77.4 per cent). High technology industries are the least preferred ones by the foreign investors according to both criteria.

Most of the firms in the sample invested in Turkey before 2000, which means that their relations with Turkish economy go a long way back. Some firms increased their shares or even acquired the whole firm in the following years. The investors originating from a large variety of countries mostly preferred brownfield investment. Considering that some of the greenfield investments are made in the form of joint venture, foreign investors have barely made greenfield investment on their own (see Table 3). 
Table 3. Country of Origin, Foreign Capital Ratio, Investment Date, and Type of Investment of the Firms in the Sample

\begin{tabular}{|c|c|c|c|c|}
\hline Firms & Country & $\begin{array}{l}\text { Foreign } \\
\text { Capital } \\
\text { Ratio }\end{array}$ & $\begin{array}{l}\text { Investment } \\
\text { Date }\end{array}$ & Type of Investment \\
\hline F1 & Switzerland & $100 \%$ & 2006 & Brownfield investment \\
\hline F2 & $\begin{array}{l}\text { Germany } \\
\left(\text { Spain }^{\mathrm{a}}\right)\end{array}$ & $39.72 \%$ & 1996 & $\begin{array}{l}\text { Foreign investor, having made a brownfield investment six } \\
\text { months ago, merged with a local firm from the same sector } \\
\text { on equal shares }\end{array}$ \\
\hline F3 & USA & $41.08 \%$ & 1983 (1997) & $\begin{array}{l}\text { Acquired } 30 \% \text { of an existing firm in } 1983 \text {; in } 1997 \text { it } \\
\text { increased its share to } 41.08 \% \text {, having the same share as the } \\
\text { local partner }\end{array}$ \\
\hline F4 & Britain & $100 \%$ & 2002 & $\begin{array}{l}\text { Greenfield investment (in 2008, it also acquired a local firm } \\
\text { from the same industry) }\end{array}$ \\
\hline F5 & $\begin{array}{l}\text { Germany } \\
\left(\text { Netherlands }^{\mathrm{a}}\right)\end{array}$ & $100 \%$ & 2003 & Brownfield investment \\
\hline F6 & $\begin{array}{l}\text { Japan } \\
(\text { Belgium } \\
\left.90 \%{ }^{\mathrm{a}}\right)\end{array}$ & $100 \%$ & $1992(2001)$ & $\begin{array}{l}\text { Foreign investor initially made a greenfield investment in } \\
\text { the form of joint venture with a local firm in 1992; it then } \\
\text { increased its share to } 100 \% \text { in } 2001 \text {. }\end{array}$ \\
\hline F7 & Japan & $43.63 \%$ & 1988 & $\begin{array}{l}\text { Brownfield investment in the form of joint venture with a } \\
\text { local firm in 1988; then a new factory in } 1989\end{array}$ \\
\hline F8 & France & $100 \%$ & 1988 & Brownfield investment \\
\hline F9 & Switzerland & $100 \%$ & 2004 & Brownfield investment (it then established a new factory) \\
\hline F10 & $\begin{array}{l}\text { India } \\
\left(\text { Netherlands }^{\mathrm{a}}\right)\end{array}$ & $100 \%$ & 1992 & $\begin{array}{l}\text { Brownfield investment in the form of joint venture (foreign } \\
\text { capital was } 60 \% \text { ) with a local firm in } 1992 \text {; then foreign } \\
\text { capital ratio gradually increased to } 100 \%\end{array}$ \\
\hline F11 & France & $51 \%$ & 1969 & Greenfield investment (joint venture) \\
\hline F12 & $\begin{array}{l}\text { Australia } \\
\left(\text { Britain }^{\mathrm{a}}\right)\end{array}$ & $100 \%$ & $1994(2000)$ & $\begin{array}{l}\text { Brownfield investment in the form of joint venture with a } \\
\text { local firm in 1994; foreign capital ratio increased to } 100 \% \\
\text { in } 2000\end{array}$ \\
\hline F13 & $\begin{array}{l}\text { Brazil } \\
\left(\text { Germany }^{\mathrm{a}}\right)\end{array}$ & $60 \%$ & $1992(2003)$ & $\begin{array}{l}\text { Foreign investor went into a partnership with a local firm } \\
\text { in } 1992 ; \text { it then made a greenfield investment in the form } \\
\text { of joint venture with the same firm. In } 2003 \text { it increased its } \\
\text { share to } 60 \%\end{array}$ \\
\hline F14 & Italy & $37.86 \%$ & 1968 & Greenfield investment (joint venture) \\
\hline F15 & $\begin{array}{l}\text { Japan } \\
\left(\text { Netherlands }^{\mathrm{a}}\right)\end{array}$ & $100 \%$ & 1993 (1999) & $\begin{array}{l}\text { Greenfield investment in } 1993 \text {. In 1999, existing foreign } \\
\text { investor acquired the firm from the former foreign investor }\end{array}$ \\
\hline
\end{tabular}

\footnotetext{
${ }^{\mathrm{a}}$ Home country is different from the country from which foreign capital flows into Turkey. The latter is shown in parentheses. Among the reasons are the facts that non-European firms transfer capital to Turkey via their regional headquarters in Europe and that some firms opt to export capital other than its original country due to the tax advantages.
}

Note: Tables 3-7 were derived from the research made by the author. 


\subsection{Results}

\section{Turkey}

\subsubsection{The most important factors leading foreign investors to invest in}

The leading factor is that labour force in Turkey, as a country close to Europe, is cheaper than Europe and more qualified than the countries which are famous for their cheap labour. In other words, the fact that relatively qualified labour force is cheap is an important factor to invest in Turkey. The expression of 'relatively cheap labour' then implies that labour force in Turkey is cheaper than the developed European countries and it is cheaper according to the qualified labour force standards. As will be seen in the analysis of the tenth question, most firms are export-oriented and the significant amount of their exports is made to Europe, which is consistent with the results of the first question. In addition, most of these firms produce medium-high technology products, meaning that they need relatively qualified labour force.

Large domestic market of Turkey is another important factor attracting foreign investors. Even the exportoriented firms highlighted the importance of Turkish domestic market. So we can easily conclude that Turkish domestic market is much more important for the foreign investors outside the universe.

When we analyse the relationships among different expressions we are able to reveal the importance of the expressions whose frequencies are low, and that some other factors are also related to the large domestic market. For instance, 'growing economy' (expressed only by one firm) and 'young population' (expressed by two firms) cannot be thought separately from the 'large domestic market' since a market of such a large size can only maintain its presence in a growing economy which contains a young population with a potential to consume. The expression of 'sectoral legal obligations' as well is indirectly related to 'large domestic market.' Two firms declared that, according to Turkish legal regulations, they have to invest and produce in Turkey in order to sell their products in Turkey. It clearly shows how Turkish domestic market is important for these firms since they run the risk of investing in Turkey just to be able to sell their products in the Turkish market.

Table 4. The Reasons for Foreign Investors to Invest in Turkey

\begin{tabular}{|l|l|}
\hline Expression Used & Frequency \\
\hline Relatively cheap labour & $\mathbf{1 0}$ \\
\hline Large domestic market & $\mathbf{1 0}$ \\
\hline Logistic location & $\mathbf{7}$ \\
\hline Closeness to Europe & $\mathbf{7}$ \\
\hline Facilities of the local partner & $\mathbf{4}$ \\
\hline Incentives & $\mathbf{3}$ \\
\hline Acquiring its rivals & $\mathbf{2}$ \\
\hline Young population & $\mathbf{2}$ \\
\hline Economic and political stability & $\mathbf{2}$ \\
\hline Disciplined labour ready to work flexibly & $\mathbf{2}$ \\
\hline Sectoral legal obligations & $\mathbf{2}$ \\
\hline Low raw material costs & $\mathbf{1}$ \\
\hline Low production costs & $\mathbf{1}$ \\
\hline Turkey-EU Customs Union Agreement & $\mathbf{1}$ \\
\hline Growing economy & $\mathbf{1}$ \\
\hline Availability of sub-industries & $\mathbf{1}$ \\
\hline Better institutional structure than the nearby geography & $\mathbf{1}$ \\
\hline High level political relations & $\mathbf{1}$ \\
\hline
\end{tabular}


'Logistic location' and 'closeness to Europe' are other highly-used expressions and they are together related to 'relatively cheap labour' because labour force in Turkey is cheap relative to Europe and among the countries around Europe. Logistic location also implies that Turkey is a significant hub between Europe and Asia, and has an easy access to its export markets such as Middle East and North Africa alongside Europe.

Another factor leading foreign investors to invest in Turkey is the desire to annihilate their rivals by acquiring them. This motivation evokes the concept of centralization used by the theorists of imperialism and Steven Hymer's market power approach. And this factor is more important than it seems: Although only two firms declared that they had invested in Turkey in order to acquire their rivals, we know from Table 3 that some other investors initially entered into partnership with local firms and then acquired all of their shares.

Two firms (F6, F13) expressed that 'disciplined labour ready to work flexibly' is a critical factor in the continuance of their investments. When we take into consideration that working conditions and hours are better, and labour regulations are much less violated in Europe, some other firms in the sample, though they did not express clearly, may have been attracted by this factor.

'Facilities of the local partner' is also among the significant factors leading foreign investors to invest in Turkey, which will be further discussed in the analysis of the second question about strategy.

\subsubsection{Strategies of the foreign investors}

While analysing the strategies of the firms investing in Turkey I considered other answers of the firms and other data about them in addition to the answers given to the question about strategy; otherwise the analysis about the strategy of the firms would underestimate some aspects.

The most common strategy followed by foreign investors is 'entering Turkish market via a local partner' (six firms expressed so). But actually, this strategy is even more important than it seems. We know from the Table 3 that nine firms entered Turkish market via a local partner (six of these firms still maintain this partnership while the other three acquired the shares of their local partners).

And this leads us to another strategy: Acquiring its rivals in Turkey. Although this expression was used three times (F2, F5, 12), three other firms (F10, F13, F15) have the same tendency: In the first example, foreign investor acquired the local firm after going into a partnership with this firm; in the second one, foreign investor acquired majority shares of the local firm after the partnership; in the third one, foreign investor acquired another foreign investor which had formerly made a greenfield investment in Turkey. Thus, six firms in total followed the strategy of acquiring its local or global rivals as a result of their monopolistic behaviours.

In addition, local partners still cooperating with foreign investors are strong firms. Five out of six firms having both foreign and local partners belong to the leading holdings in Turkey, have close relations with the political authority and dominate the domestic market. Thus, the main purpose of foreign investors in choosing this strategy is both to use local partners as a facilitator element by benefiting from their political and economic ties, and to realize fast and high returns on their investment via the position of the local partners in the domestic market.

Another important strategy is to utilize the 'position of Turkey in the global logistics network of the parent company'. The firms following this strategy generally intend to make use of Turkey's position as a transit point between Europe on the one hand and Middle East, Asia, North Africa on the other hand. And this strategy can be associated with 'turning toward close export markets through Turkish domestic market.' 
Table 5. The Strategies Followed by Foreign Investors While Investing in Turkey

\begin{tabular}{|c|c|}
\hline Expression Used & Frequency \\
\hline Entering Turkish market via a local partner & 6 \\
\hline Position of Turkey in the global logistics network of the parent company & 4 \\
\hline Acquiring its rivals & 3 \\
\hline Following growing domestic markets & 3 \\
\hline Turning toward close export markets through Turkish domestic market & 2 \\
\hline Following the behaviours of the other global players in the market & 2 \\
\hline Acquiring an existing firm and then expanding it & $\mathbf{1}$ \\
\hline Considering the past experiences in Turkey & 1 \\
\hline Specializing in a certain product line in Turkey & 1 \\
\hline Acquiring other firms in the industry after making greenfield investment & $\mathbf{1}$ \\
\hline Managing both the strategy towards domestic market and export & $\mathbf{1}$ \\
\hline $\begin{array}{l}\text { Making small-scale investment at first, and then evaluating to increase the investments according } \\
\text { to the course of the existing business }\end{array}$ & 1 \\
\hline Merger and Acquisition decisions of the foreign investor in the global level & $\mathbf{1}$ \\
\hline Acting according to the local legal regulations in the industry & 1 \\
\hline Acting according to the raw material supply chain & 1 \\
\hline $\begin{array}{l}\text { Determining the production facilities which are able to produce certain products and then } \\
\text { comparing costs among the related countries }\end{array}$ & 1 \\
\hline
\end{tabular}

Although 'following growing domestic markets' was used three times, we know from the first question that much more foreign investors target domestic market while investing in Turkey. 'Merger and Acquisition decisions of the foreign investor in the global level' and 'following the behaviours of the other global players in the market' are also related to each other. Both strategies imply that giant TNCs have their wits about each other, and eliminate their counterparts if need be. Such acts directly affect their extensions in Turkey.

\subsubsection{Incentives given by the Turkish state}

Most of the foreign investors (eleven firms) received investment incentives from the Turkish state during the investment process. Three out of four firms that did not receive any incentive from the state made brownfield investment. However, foreign investors receiving incentives benefited from the same incentives offered to the local firms; namely, foreign firms did not receive any exclusive incentive.

\subsubsection{International agreements facilitating foreign investment}

There is not any firm expressing that it benefited from an international agreement. And a few firms (F2, F3, F4, F13) declared that international arbitration arrangement helped to increase their investment in Turkey. Most firms indicated that their investment can be traced back to the pre-1999 - the date when international arbitration law was enacted. One firm (F13) clearly stated that it increased its shares after the enactment of the international arbitration law. The effects of international arbitration are indirect for three other firms: They see international arbitration as a guarantee for their investments. 


\subsubsection{Foreign investments of the firms in other countries}

All of the firms in the sample are giant TNCs having production facilities in tens of countries, employing tens of thousands of people, and generating tens (for some firms hundreds) of billions of USD in revenue. Eight out of fifteen firms in the sample rank among the top 100 non-financial TNCs listed by UNCTAD. Some foreign investors are either the world's biggest firms or among top three in their industry. Total revenues of these fifteen firms in 2013 are $\$ 885$ billions, which is a little higher than Turkey's GDP that year. Their total number of employees is 1.59 million. Foreign firms investing in Turkey are global firms investing not only in Turkey or other similar developing countries but all over the world and managing huge global production networks.

\section{Turkey}

\subsubsection{Technology transfer by foreign investors and their R\&D units in}

Foreign investors largely brought their own production technologies into Turkey: They introduced a production technique and/or a production line which did not exist before, or their own know-how and/or right of use of a patent into Turkey. Indeed some local firms expressed that they went into a partnership with foreign firms due to their production technology.

Unsurprisingly, two out of five firms (F1, F2, F5, F12, F15) declaring that foreign investor have not brought a new technology operate in low technology industries, and two other operate in medium-low technology industries.

Eight out of fifteen firms do not have any R\&D unit in Turkey although they have some units in the other countries. And foreign capital ratio of seven out of these eight firms is 100 per cent. Out of the nine firms whose foreign capital ratio is 100 per cent, only two (F5, F8) has a R\&D unit in Turkey. Furthermore, these R\&D units are small-scale ones focused on the needs of the local markets. The firms possessing significant R\&D units (F2, F3, F13, F14) have strong local partners. R\&D units of two firms (F3, F11) employ experts from the country of the foreign firm. To summarize, global firms operating production facilities and R\&D units in a dozen of countries do not classify Turkey as a R\&D centre in the manufacturing industry.

\subsubsection{Qualification of the workforce employed in the production process}

Educational level of the employees working in the production units of the foreign investors has generally increased in the last 15-20 years. While primary or secondary school graduates were in majority formerly, most of them are high school or vocational school graduates nowadays. Vocational schools became so important for these firms that one foreign investor (F3) together with its local partner established a vocational school itself.

Indeed, in the last few years, private vocational high schools and their number of students have increased dramatically. The main reason is an amendment in the Law of Private Schools in 2012. Accordingly, the government would give financial support for each student studying in the private vocational and technical high schools. As a result, the number of private vocational and technical high schools increased from 45 in the school year 2011-2012 to 126 in 2012-2013 and to 426 in 2013-2014. The number of students in these private schools climbed from 4,348 to 17,854 and to 56,053 respectively (Milli Eğitim Bakanlığı, 2014: 17). Thus the state withdrew to some extent from vocational and technical training, which is considered as a burden, transferred a considerable amount of income to private firms, and encouraged initiatives to supply intermediate staff needed by the Turkish manufacturing industry. 


\subsubsection{Main reasons for using domestic or imported inputs}

The use of imported inputs of the firms in the sample is very high. 80 per cent or more of the inputs used by five firms (F1, F4, F9, F12, F15) are imported. More than half of the inputs used by six firms (F2, F3, F7, F8, F11, F14) are imported. Only three firms (F5, F6, F13) use imported inputs less than 50 per cent of their total inputs. One firm's (F10) imported input ratio varies between 5 and 90 per cent according to the world price and supply conditions of that year. If we take into consideration that some of the intermediate goods bought from the local suppliers are imported by these suppliers themselves, the imported input ratios of the foreign-invested manufacturer-exporters are even higher than it seems.

The most important reason for using imported inputs is that the required inputs are not produced in Turkey or their production is insufficient (11 firms expressed so). These are raw materials which are not present in Turkey, too expensive products to produce, or products Turkey fails to produce due to the technological incompetence. This expression is to some extent related to 'low cost' since some inputs are imported not because they cannot be produced in Turkey but they cannot be produced at a lower cost. Other factors making 'low cost' important are that some countries (especially Southeast Asian ones) achieve very competitive prices owing to the low labour costs and economies of scale, and cheap import options for Turkey as a result of the overvalued Turkish lira from the early 1990s onwards. Another important reason is directly importing from parent company or global supply agreements of the parent company (8 firms).

As for the reasons for using domestic inputs, the most important ones are strong local suppliers and logistic advantage. Especially for automotive industry foreign investors make use of strong supply industry. Low cost is also essential for domestic inputs but this time it is related to easy access to inputs.

\subsubsection{Intermediate goods exports}

Five out of fifteen firms (F1, F2, F6, F7, F12) do not export any intermediate goods or their exports are negligible. All or nearly all of the exports of three firms (F5, F10, F13) consist of intermediate goods since they only produce intermediate goods. Intermediate goods exports of three other firms (F4, F9, F14) form a tiny part of their total exports.

The most significant data is that five out of ten intermediate goods exporters (F3, F8, F9, F11, F15) make all or most of their intermediate goods exports to the foreign affiliates of the parent companies. This confirms that the production facilities in Turkey are part of global production networks governed by the global firms (see twelfth question for further detail).

\subsubsection{Main rivals in the export markets}

Most of the firms in the sample are among world leaders in their export markets. The principal reason is that they are affiliates or partners of the world's top TNCs. Ten firms makes most of their exports to European countries, which is consistent with the export breakdown of the Turkish manufacturing industry and the expression of 'closeness to Europe' that foreign investors ranked among the most important factors while investing in Turkey.

The firms whose main export market is not Europe export largely to the Middle East, Africa (especially North Africa), and Russia. The greatest part of the exports is made to close countries, which proves that Turkey's logistic location is important for the export-oriented foreign investors. 


\subsubsection{Procurement of capital goods and inputs directly imported from the parent company}

All of the firms in the sample import the large part of the capital goods they use. Although some firms (F2, F4, F6, F7, F8, F9, F13) also buy capital goods from Turkish firms, they constitute only a tiny part of their use of capital goods and are small-scale ones. That is to say, the Turkish manufacturing industry generally fails to produce capital goods.

Firms importing capital goods principally procure them in three ways: import from parent company's contracted suppliers, direct import, and import from parent company. Apart from capital goods, nine firms (F3, F4, F6, F7, F9, F10, F11, F14, F15) import several inputs from the parent company, which means that they are thoroughly integrated to them.

\subsubsection{Global production networks / global supply chains to which the firms}

\section{belong}

All of the fifteen firms are affiliates of giant TNCs organizing a global production network or global supply chain. Most of them conduct production, import, export, relations between units in different countries, and even collection of debts quite centrally. And the units in Turkey act on the centrally taken decisions.

Table 6 shows the most frequent expressions about the relationships of the production units in Turkey with their parent companies. Accordingly, the expressions about 'the relationships of the production unit in Turkey with the other units,' 'procurement of inputs,' and 'determining the target markets' are the most frequent ones.

Table 6. The Relationships Defining Global Supply / Production Networks to which the Firms Belong

\begin{tabular}{|l|l|}
\hline Expression Used & Frequency \\
\hline The relationships between the unit in Turkey and the units in other countries are conducted via & $\mathbf{1 2}$ \\
\hline Procurement of inputs are largely organized by the parent company & $\mathbf{1 1}$ \\
\hline Parent company decides the markets to which the goods produced in Turkey are sold & $\mathbf{9}$ \\
\hline Parent company decides which product will be produced in which country & $\mathbf{8}$ \\
\hline Intermediate goods are traded between the unit in Turkey and the units in other countries & $\mathbf{7}$ \\
\hline The payments for the goods exported from Turkey are made to parent company & $\mathbf{3}$ \\
\hline The unit in Turkey belongs to one of regional clusters constituted by the parent company & $\mathbf{2}$ \\
\hline The unit in Turkey is part of a multilocal chain & $\mathbf{1}$ \\
\hline
\end{tabular}

All but one (F2) of the firms' parent companies manage huge global production networks or global supply chains. This remaining firm organizes a multilocal production and supply chain due to the sectoral characteristics. One firm (F5) is not closely tied to the production network of the parent company since the parent company barely interfered in its affiliate after acquiring it because it has a dominant position in the market and a successful production organization. Three other firms (F7, F10, F13) have loose relations with their parent companies; two of them (F7, F13) have strong local partners. 
However, in general, parent company determines which products to be produced in Turkey, organizes the procurement of most inputs, decides where to export, and arranges the relationships between the production units in Turkey and the units in other countries.

\subsubsection{Using contract manufacturers}

Eleven firms do not use contract manufacturers; they conduct the whole production process within their own production unit. Total amount of the contract production of the remaining four firms using contract manufacturers occupies a small space within their total production. Contract manufacturers of these four firms are from Turkey.

Furthermore, they do not use a contract manufacturer from a foreign country at all. At first, this fact may connote that the production units in Turkey are loosely integrated with the production units abroad, but this may be explained in two ways: Firstly, the production units in Turkey have certain roles within these networks, and secondly (and related to the first), the units in Turkey do not have such a position as organizing contract manufacturing operations abroad on their own. Parent companies themselves manage contract manufacturing operations in other countries.

\subsubsection{Doing contract manufacturing for foreign firms}

Fourteen out of fifteen firms do not do contract manufacturing for foreign firms. One among them does contract manufacturing only for a domestic firm, but this is not more than 1-2 per cent of the total production.

There is only one firm (F14) doing contract manufacturing for foreign firms. This firm makes some modifications on the existing products upon demands of the foreign firms. It uses the same production line for the contract manufacturing as well as for its own production. These contract manufacturing deals are made by the parent company in accordance with demand from other TNCs.

\subsubsection{The influence of the directors of the firm in Turkey, and foreign and Turkish shareholders on the decisions taken}

In general, foreign investors take the main decisions. In some cases, Turkish partner or the directors in Turkey may have some influence on the decisions. Most frequently used expression is that major decisions are taken by the parent company. 'Major decisions' imply new investment decisions, increase in the production levels, purchasing decisions above a certain limit, deciding which product to be produced in Turkey, determining the price of a product etc. The influence of the Turkish partner or directors in Turkey on such decisions is very limited. In some firms (F3, F12, F14, F15) foreign investors pay attention to the opinions of the directors in Turkey. Some other firms expressed that directors in Turkey can only take decisions below a certain budget. In some cases, the role of the directors in Turkey is restricted to making effort to canalize new investments to Turkey. 
Table 7. The Influence of Foreign and Turkish Partners on the Decisions Taken

\begin{tabular}{|l|l|}
\hline Expression Used & Frequency \\
\hline Major decisions are taken by the parent company & $\mathbf{1 0}$ \\
\hline The influence of the directors in Turkey on the decisions is relatively strong & $\mathbf{4}$ \\
\hline Directors in Turkey can take decisions below a certain budget & $\mathbf{4}$ \\
\hline Opinions of the directors in Turkey are considered & $\mathbf{4}$ \\
\hline Decisions taken are based on consensus & $\mathbf{3}$ \\
\hline Approval of the foreign investor is required for new investment decisions & $\mathbf{2}$ \\
\hline Directors in Turkey make effort to canalize foreign investments to Turkey & $\mathbf{2}$ \\
\hline
\end{tabular}

There are some firms in which the influence of the directors in Turkey on the decisions is relatively strong. The most important reason why Turkish directors have some influence is that local partners are powerful. But in two of these firms, approval of the parent company is required for new investment decisions because parent company's technology would be used in new investments.

\section{Conclusion}

Internationalization of production, having intensified from the 1970s and 1980s onwards in parallel with internationalization of capital, has had several and various effects on the Turkish manufacturing industry and its place in the international capitalist system.

The study clearly shows that the main reasons why foreign firms invest in Turkey are that Turkey has relatively cheap and qualified labour force among the countries close to Europe, and Turkey has an enlarging domestic market. Turkey's logistic location is another important factor. The most common strategy followed by foreign investors is 'entering Turkish market via a local partner.' They largely brought their own production technologies into Turkey but most of them do not have any R\&D department in Turkey. Large part of the inputs they use is imported, and the main reasons are the lack of adequate supply in Turkey and global supply agreements of the parent companies. Foreign investors attach importance to technical high schools and vocational schools. They generally operate in medium-high and medium-low technology industries (automotive, chemistry, and food are the most preferred ones) and they mainly export to Europe. All of the firms are affiliates of giant TNCs and each of them organizes a global production network or a global supply chain. Procurement of inputs, production decisions, target markets, relations between units in different countries are determined by the parent company, and in general, foreign investors take the main decisions.

As a result, with these roles assigned to the Turkish manufacturing industry in the international division of labour, internationalization of production obviously reinforced foreign-dependent structure of the Turkish manufacturing industry. In addition, although Turkey takes bigger and bigger part in the international economic organisation it slips down the rankings especially in the high-tech areas. Turkey is an intermediate zone between advanced Western countries and cheap labour Asian countries. And we can describe Turkey as a periphery economy or backyard of Europe. Undoubtedly, some upgrading possibilities exist as seen in the literature; however, they took place in either low-tech industries (such as textiles and apparel) or some processes of the medium-high technologies. Nevertheless, it is worth to discuss, especially for Turkish automotive industry, the potentials to upgrade within the global automotive industry, with its ever increasing exports and developing supply industry. But one should keep in mind that global automotive industry bear oligopolistic characteristics and the international production mechanisms should require and let such a transformation. 
The most problematic issue is that Turkish manufacturing industry has no more chance to compete on the basis of cheap labour. Because, on the one hand, with the enlarging domestic market, wage levels has increased to some extent, and on the other hand Turkey has great difficulties in competing with China and other Asian countries in the global level and with Eastern European countries in the regional level.

Within this framework, the only advantage for Turkey is the fact that 'relatively qualified' labour force is cheap. The recent agenda in Turkey about establishing at least one university in each city (without regarding the quality of these universities) and the desire to increase the population by suggesting to increase the number of children should be evaluated in this context.

Considering the impossibility of Turkish manufacturing industry to compete on the basis of cheap labour, the policies of escalating the rate of fertility and increasing merely the number of universities without any concern about the quality of the education system, along with the policies encouraging the dependency on the imported input should be questioned. However, it seems that the role of Turkish manufacturing industry in the international division of labour requires the aforementioned characteristics: abundant labour force being qualified to some extent. Statements of the government authorities that "Turkey is the China of Europe' ${ }^{4}$ and 'Turkey is a country of intermediate staff' ${ }^{5}$ confirm this situation as well. Just as Marshall Plan considered Turkey for the production of agricultural goods and agriculturebased industry in the post-World War II period, and import-substitution period imposed assembly lines on the Turkish manufacturing industry; internationalization of production assigned it to specialize on medium-high (especially automotive industry except for designing and high-technology processes) and medium-low technology industries requiring relatively qualified and abundant labour force.

\footnotetext{
4 The expression of 'Turkey is the China of Europe' was first brought up by The Economist in its issue on 23 October 2010 and the then state minister in charge of foreign trade embraced it.

5 The then minister of environment and urbanisation told in a speech in August 2013: 'We are a country of intermediate staff, we cannot bring up inventors; we cannot make inventions due to our situation. We should train technical intermediate staff.' (Habertürk, 2013; Radikal, 2013) And this discourse cannot be separated from the first one.
} 


\section{References}

Atıcı, G. ve Gürsoy, G. (2012). Foreign Direct Investment and Export Decision Relationship in the Large Turkish Firms. Journal of Applied Finance \& Banking, 2(4), 167-84.

Bair, J. (2005). Global Capitalism and Commodity Chains: Looking Back, Going Forward. Competition \& Change, 9(2), 153-80.

Coe, N. M., Dicken, P. and Hess, M. (2008). Global Production Networks: Realizing the Potential. Journal of Economic Geography, 8(3), 271-95.

Çatık, A. N. and Karacuka, M. (2012). A Spatial Approach to Measure Productivity Spillovers of Foreign Affiliated Firms in Turkish Manufacturing Industries. The Journal of Developing Areas, 46(2), 65-83.

Davis, J. B. (2004). Transnational Corporations: Dynamic Structures, Strategies, and Processes. In P. A. O’Hara (ed.), Global Political Economy and the Wealth of Nations: Performance, Institutions, Problems, and Policies (pp. 129-146). London: Routledge. Economics, 35(16), 1767-1778.

Dikmen, A. A. (2007). Primitive Accumulation Via Global Production: The Case Only of Underdeveloped Countries. Social Scientist, 35(7/8), 44-60.

Dunning, J. H. (2001). The Eclectic (OLI) Paradigm of International Production: Past, Present and Future. International Journal of the Economics of Business, 8(2), 173-90.

Ebghaei, F. and Akkoyunlu-Wigley, A. (2018). The Role of Exports in the Transmission of Horizontal and Vertical Spillovers of Foreign Direct Investment: The Case of Turkish Manufacturing Industry. The Developing Economies, 56(1), 35-50.

Forsgren, M. (2008). Theories of the Multinational Firm: A Multidimensional Creature in the Global Economy. Cheltenham: Edward Elgar.

Fröbel, F., Heinrichs, J. and Kreye, O. (1977). The Tendency Towards a New International Division of Labor: The Utilization of a World-Wide Labor Force for Manufacturing Oriented to the World Market. Review, 1(1), 73-88.

Fröbel, F., Heinrichs, J. and Kreye, O. (1978). The New International Division of Labor. Social Science Information, 17(1), 123-42.

Gereffi, G. (1994). The Organization of Buyer-Driven Global Commodity Chains: How U.S. Retailers Shape Overseas Production Networks. In G. Gereffi \& M. Korzeniewicz (eds.), Commodity Chains and Global Capitalism (pp. 95-122). Westport, Connecticut: Praeger.

Habertürk (2013, $\quad$ September $\quad$ 2). $\quad$ Rant Ulmazsa Ülke $\quad$ Kalkınmaz http://www.haberturk.com/gundem/haber/874181-rant-olmazsa-ulke-kalkinmaz. Retrieved Sep 2, 2013.

Henderson, J., Dicken, P., Hess, M., Coe, N. and Yeung, H. W.-C. (2002). Global Production Networks and the Analysis of Economic Development. Review of International Political Economy, 9(3), 436-64.

Hilferding, R. (2006). Finance Capital: A Study of the Latest Phase of Capitalist Development (translated by M. Watnick \& S. Gordon). London: Routledge.

Hobson, J. A. (2005). Imperialism: A Study. New York: Cosimo (originally published in 1902).

Hopkins, T. K. and Wallerstein, I. (1977). Patterns of Development of the Modern World-System. Review, 1(2), $111-45$.

Hopkins, T. K. and Wallerstein, I. (1986). Commodity Chains in the World-Economy Prior to 1800. Review, 10(1), $157-70$.

Hymer, S. H. (1960). The International Operation of National Firms, A Study of Direct Foreign Investment. $\mathrm{PhD}$ diss. Massachusetts Institute of dspace.mit.edu/bitstream/handle/1721.1/27375/02013925-MIT.pdf?sequence=2. Retrieved Mar 2, 2015. 
Johanson, J. and Wiedersheim-Paul, F. (1975). The Internationalization of the Firm - Four Swedish Cases. Journal of Management Studies, 12(3), 305-22.

Kanberoğlu, Z. and Kara, O. (2014). Türk İmalat Sanayi Katma Değeri Üzerinde Doğrudan Dış Yatırımların Rolü. Dumlupınar Üniversitesi Sosyal Bilimler Dergisi, 39, 129-44.

Lenger, A. and Taymaz, E. (2006). To Innovate or to Transfer? A Study on Spillovers and Foreign Firms in Turkey. Journal of Evolutionary Economics, 16(1-2), 137-53.

Lenin, V. I. (1964). Collected Works Volume 22: December 1915-July 1916 (translated by Yuri Sdobnikov). Moscow: Progress Publishers.

Milli Eğitim Bakanlı̆̆ı (2014). Milli Ĕğtim İstatistikleri: Örgün Eğitim, 2013-2014, Ankara: MEB.

National Science Board (2012). Science and Engineering Indicators 2012: Appendix Tables, Arlington, VA: National Science Foundation.

National Science Board (2014). Science and Engineering Indicators 2014: Appendix Tables, Arlington, VA: National Science Foundation.

National Science Board (2018). Science and Engineering Indicators 2018: Appendix Tables, Arlington, VA: National Science Foundation.

Neidik, B. and Gereffi, G. (2006). Explaining Turkey's Emergence and Sustained Competitiveness as a Full. Package Supplier of Apparel. Environment and Planning A, 38(12), 2285-2303.

Nixson, F. (2002). Industrialization and Industrial Policy. In C. Kirkpatrick, R. Clarke \& C. Polidano (eds.), Handbook on Development Policy and Management (pp. 68-77). Cheltenham: Edward Elgar Publishing.

Ok, S. T. (2004). What Drives Foreign Direct Investment into Emerging Markets? Evidence from Turkey. Emerging Markets Finance and Trade, 40(4), 101-14.

Özatağan, G. (2011). Shifts in Value Chain Governance and Upgrading in the European Periphery of Automotive Production: Evidence from Bursa, Turkey. Environment and Planning A, 43(4), 885-903.

Özuğurlu, M. (2008). Anadolu'da Küresel Fabrikanın Doğuşu: Yeni İşçilik Örüntülerinin Sosyolojisi, İstanbul: Kalkedon Yayınları.

Polat, B. and Payaslığlu, C. (2015). Determinants of Foreign Direct Investment to Turkey: A Sectoral Approach. Topics in Middle Eastern and African Economies, 17(2), 1-28.

Radikal (2013, August 6). Bayraktar: Müslüman Ülkeyiz Bizden Mucit Çımaz. http://www.radikal.com.tr/turkiye/bayraktar-musluman-ulkeyiz-bizden-mucit-cikmaz-1145117. Retrieved Aug 6, 2013.

Sekmen, F. (2013). İmalat Sanayi Dış Ticaret Analizi. Kalkınma Dergisi, 70, 2-13.

Selwyn, B. (2012). Beyond Firm-Centrism: Re-Integrating Labour and Capitalism into Global Commodity Chain Analysis. Journal of Economic Geography, 12(1), 205-26.

Selwyn, B. (2016). Global Value Chains and Human Development: A Class-Relational Framework. Third World Quarterly, 37(10), 1768-86.

Tatoğlu, E. and Glaister, K.W. (1998). Western MNCs' FDI in Turkey: An Analysis of Location Specific Factors. Management International Review, 38(2), 133-59.

Tatoğlu, E., Glaister, K.W. and Erdal, F. (2003). Determinants of Foreign Ownership in Turkish Manufacturing. Eastern European Economics, 42(2), 5-41.

Taymaz, E. and Özler, Ş. (2007). Foreign Ownership, Competition, and Survival Dynamics. Review of Industrial Organization, 31(1), 23-42. 
Tokatli, N. (2003). Globalization and the Changing Clothing Industry in Turkey. Environment and Planning A, 35(10), 1877-94.

Tokatli, N. (2007). Asymmetrical Power Relations and Upgrading Among Suppliers of Global Clothing Brands: Hugo Boss in Turkey. Journal of Economic Geography, 7(1), 67-92.

Tokatli, N. and Eldener, Y. B. (2004). Upgrading in the Global Clothing Industry: The Transformation of Boyner Holding. Competition \& Change, 8(2), 173-93.

Tokatli, N. and Kızılgün, Ö. (2004). Upgrading in the Global Clothing Industry: Mavi Jeans and the Transformation of a Turkish Firm from Full-Package to Brand-Name Manufacturing and Retailing. Economic Geography, $80(3), 221-40$.

Tokatli, N., Kızılgün, Ö. and Cho, J. E. (2011). The Clothing Industry in Istanbul in the Era of Globalisation and Fast Fashion. Urban Studies, 48(6), 1201-15.

TÜİK. (2017). Dış Ticaret İstatistikleri Aralı 2017. http://www.tuik.gov.tr/PreHaberBultenleri.do?id=27783. Retrieved Feb 24, 2018.

UNCTAD. (1997). World Investment Report 1997: Transnational Corporations, Market Structure and Competition Policy. New York and Geneva: United Nations.

UNCTAD. (1999). World Investment Report 1999: Foreign Direct Investment and the Challenge of Development. New York and Geneva: United Nations.

UNCTAD. (2000). World Investment Report 2000: Cross-border Mergers and Acquisitions and Development. New York and Geneva: United Nations.

UNCTAD. (2001). World Investment Report 2001: Promoting Linkages. New York and Geneva: United Nations.

UNCTAD. (2002). World Investment Report 2002: Transnational Corporations and Export Competitiveness. New York and Geneva: United Nations.

UNCTAD. (2003). World Investment Report 2003: FDI Policies for Development: National and International Perspectives. New York and Geneva: United Nations.

UNCTAD. (2005). World Investment Report 2005: Transnational Corporations and the Internationalization of $R \& D$. New York and Geneva: United Nations.

UNCTAD. (2007). World Investment Report 2007: Transnational Corporations, Extractive Industries and Development. New York and Geneva: United Nations.

UNCTAD. (2009). World Investment Report 2009: Transnational Corporations, Agricultural Production and Development. New York and Geneva: United Nations.

UNCTAD. (2012). World Investment Report 2012: Towards a New Generation of Investment Policies. New York and Geneva: United Nations.

UNCTAD. (2014). World Investment Report $2014 \quad$ Annex http://unctad.org/en/PublicationChapters/wir2014Annex_en.pdf. Retrieved Oct 18, 2015.

UNCTAD. (2015). World Investment Report 2015: Reforming International Investment Governance. New York and Geneva: United Nations.

UNCTAD. (2016). Trade and Development Report 2016: Structural Transformation for Inclusive and Sustained Growth. Geneva: UNCTAD.

UNCTAD. (2017). World Investment Report 2017: Investment and the Digital Economy. New York and Geneva: United Nations.

UNCTAD Statistics. http://unctadstat.unctad.org/wds/ReportFolders/reportFolders.aspx. Retrieved Feb $23,2018$. 
Vernon, R. (1966). International Investment and International Trade in the Product Cycle. The Quarterly Journal of Economics, 80(2), 190-207.

Vernon, R. (1979). The Product Cycle Hypothesis in a New International Environment. Oxford Bulletin of Economics \& Statistics, 41(4), 255-67.

World Trade Organization (WTO). International Trade and Market Access Data. http://www.wto.org/english/res_e/statis_e/statis bis_e.htm?solution=WTO\&path=/Dashboards/MAPS\&file= Map.wcdf\&bookmarkState $=\{\% 22 \mathrm{impl} \% 22: \% 22$ client $\% 22, \% 22$ params $\% 22:\{\% 22$ langParam $\% 22: \% 22 \mathrm{en} \% 2$ 2\}\}. Retrieved Feb 23, 2018.

Appendix A. Research Questions

\begin{tabular}{|c|c|c|c|}
\hline & $\begin{array}{l}\text { Foreign Investment } \\
\text { Process }\end{array}$ & $\begin{array}{l}\text { Export Products and } \\
\text { Production Technology }\end{array}$ & $\begin{array}{l}\text { Integration into the World } \\
\text { Economy }\end{array}$ \\
\hline Question 1 & $\begin{array}{l}\text { What are the most } \\
\text { important factors leading } \\
\text { foreign investor to invest } \\
\text { in Turkey? }\end{array}$ & $\begin{array}{l}\text { Did foreign investment } \\
\text { lead to any inward } \\
\text { technology transfer? Is } \\
\text { there any R\&D unit? If so, } \\
\text { how many of the } \\
\text { employees are from the } \\
\text { foreign } \\
\text { country? }\end{array}$ & $\begin{array}{l}\text { How do you procure capital } \\
\text { goods? What is the share of } \\
\text { imported inputs coming from } \\
\text { the parent company? }\end{array}$ \\
\hline Question 2 & $\begin{array}{l}\text { Does the firm have any } \\
\text { strategy while investing in } \\
\text { Turkey? }\end{array}$ & $\begin{array}{l}\text { What is the qualification } \\
\text { of the workforce } \\
\text { employed in the } \\
\text { production process? }\end{array}$ & $\begin{array}{l}\text { Is there a global commodity } \\
\text { chain / global production } \\
\text { network / global supply chain } \\
\text { to which you belong? }\end{array}$ \\
\hline Question 3 & $\begin{array}{l}\text { Did the firm receive any } \\
\text { support or incentive } \\
\text { during the foreign } \\
\text { investment process? }\end{array}$ & $\begin{array}{lrr}\text { What are the most } \\
\text { important reasons } & \text { of } \\
\text { using domestic } & \text { or } \\
\text { imported inputs? } & \end{array}$ & $\begin{array}{l}\text { Do you use contract } \\
\text { manufacturers? If so, how } \\
\text { many of them are foreign } \\
\text { firms? }\end{array}$ \\
\hline Question 4 & $\begin{array}{l}\text { Did the firm make use of } \\
\text { an international } \\
\text { agreement during the } \\
\text { foreign investment } \\
\text { process? Did the practices } \\
\text { such as international } \\
\text { arbitration make foreign } \\
\text { investment easier? }\end{array}$ & $\begin{array}{l}\text { Do you export } \\
\text { intermediate goods? }\end{array}$ & $\begin{array}{l}\text { Do you do } \\
\text { manufacturing for } \\
\text { firms? }\end{array}$ \\
\hline Question 5 & $\begin{array}{l}\text { Does the firm have any } \\
\text { investments in other } \\
\text { countries? If so, what are } \\
\text { their extents? }\end{array}$ & $\begin{array}{l}\text { Evaluate, by taking into } \\
\text { consideration } \\
\text { countries to which you } \\
\text { export, your rivals in the } \\
\text { export markets and your } \\
\text { position against these } \\
\text { rivals. }\end{array}$ & $\begin{array}{l}\text { (If foreign capital ratio is } \\
100 \% \text { ) What is the influence } \\
\text { of the directors of the firm in } \\
\text { Turkey on the decisions } \\
\text { taken? } \\
\text { (Ifforeign capital ratio is not } \\
100 \% \text { ) What is the influence } \\
\text { of the foreign and Turkish } \\
\text { shareholders on the } \\
\text { decisions? }\end{array}$ \\
\hline
\end{tabular}

